\title{
Ancaman Ular: Signifikan dan Teknik Kawalan Menurut Perspektif Fiqh al-Hadīth
}

\author{
Mohd Farhan Md Ariffin \\ Universiti Malaya, al.muqarrobiin@gmail.com \\ Muhammad Adam Abd. Azid \\ Universiti Malaya, adamsaifulislam@gmail.com \\ Ahmad Za'im Sabirin Mohd Yusoff \\ Universiti Malaya, sabirinyusoff92@gmail.com
}

\begin{abstract}
Abstrak
Ular merupakan haiwan yang amat digeruni. Dalam kalangan masyarakat Malaysia, ular dianggap sebagai musuh yang boleh menyebabkan kematian. Buktinya, saban tahun pasti terdapat korban akibat patukan ular. Oleh itu, kaedah pencegahan awal dalam bentuk ilmu pengetahuan amat penting dalam rangka memahami konsep "interaksi dengan haiwan" dengan baik sekaligus mengelakkan sebarang konflik mendatang. Signifikannya, Nabi SAW telah membincangkan mengenai bahaya dan ancaman kelompok haiwan tertentu termasuk ular dalam himpunan sabdanya. Justeru, makalah ini berusaha mengupas fiqh alhadith berkenaan ular yang boleh didapati daripada perbincangan ulama' Ini penting bagi memberi panduan kepada masyarakat akan mudarat yang mampu dihadirkan haiwan tertentu dan teknik kawalan paling berkesan menurut al-Sunnah tanpa meminggirkan hak-hak eksklusif haiwan.
\end{abstract}

Kata kunci: ular, ancaman, haiwan perosak, teknik kawalan signifikan

\section{Snake Threat: Significant and Control Technique from the Perspective of Fiqh al-Hadīth}

\section{Abstract}

Snake is a much-feared animal. In the Malaysian society, snake is considered as an enemy that can cause death. Every year, there must be a victim of snakebite. In Islam, this type of animal is dubbed as pest (hayāwān fawāsiq). Therefore, an early preventive control measure in form of knowledge is important in order to highlight the concept of interaction with pest as well as to avoid any future conflicts. Significantly, Prophet Muhammad SAW has warned of potential threats posed by pests cluster including snakes in his set saying. Thus, this article strives to analyze regarding snakes description and specific interaction methods through fiqh al-hadith. This article is important in terms of providing guidance to society regarding harms that able to be incarnated by particular animals. Also, the most efficient control 
techniques according to Hadith without marginalizing animal exclusive rights.

Keywords: snake, threat, pest, significant control technique

\section{Pendahuluan}

Dari 'Á'ishah r.a., Nabi SAW pernah bersabda: "Lima (jenis) haiwan yang fasiq dan boleh dibunuh walaupun di tanah haram iaitu: tikus, kala jengking, burung helang, burung gagak dan anjing liar."

(Hadith Riwayat al-Bukhārīi) ${ }^{1}$

Lafaz "haiwan fasiq" dalam hadith bermaksud haiwan perosak, liar, buas, jahat, pengganggu, penceroboh dan berbahaya kepada manusia. ${ }^{2}$ Kalimah khams fawāsiq dalam hadith merujuk kepada lima jenis haiwan perosak utama, iaitu tikus, kala jengking, helang, gagak dan anjing liar. Namun, ia tidak terhad pada lima haiwan tersebut. Nabi Muhammad SAW turut menyebutkan ular dan cicak dalam riwayat lain. ${ }^{3}$

\section{Fasiq Menurut Pandangan Ulama'}

Al-Qurțubī dalam tafsirnya, Al-Jāmi' li Aḥkām al-Qur'ān ada menyatakan bahawa "fasiq" bermakna "keluar" (yakni) "keluar" dari jalan syariat Islam. "Keluar" (melanggar) perintah Allah SWT, "keluar" (tidak mengambil) apa yang dihalalkan dan menghalalkan perkara diharamkan Allah SWT. Maka, setiap kelakuan mungkar adalah tergolong fasiq (dosa). ${ }^{4}$

Ibn Abu Hatim dalam tafsirnya, Tafsìr al-Qur'ān al- 'Azìm, menyatakan "fasiq" merujuk kepada beberapa pengertian: [Pertama]: golongan yang tidak berhukum dengan hukum Allah

\footnotetext{
Hadith riwayat al-Bukhārī, Kitāb Bada'a al-Khalq, Bāb Khams min al-Dawāb Yaqtulunna fi al-Harām, no. Hadith 4414. Lihat Abū 'Abd Allāh Muhammad Ibn Ismā‘̄̄l al-Bukhārī, "Al-Jāmi' al-Musnad min Hadīth Rasūl Allāh wa Sunanih wa Ayyāmih," dalam Mawsū'at al-Hadīth al-Sharīf al-Kutub alSittah, ed. Șāliḥ Ibn 'Abd al-Azīz Āl al-Syakh (Riyadh: Dār al-Salām li alNashr wa al-Tawzī', 2000), 267.

2 Ibn Manẓūr, Lisān al- 'Arab (Kaherah: Dar al-Ma'ārif, t.t.), 5: 3413-3414.

3 Ibn Hajar al-'Asqalān̄i, Fatḥ al-Bārī bi Sharh Șaḥịh al-Bukhārī, terj. Amiruddin et al. (Jakarta: Pustaka Azzam Penerbit Buku Islam Rahmatan, 2006), 10: 195-196.

4 Abū 'Abd Allāh Muḥammad Aḥmad al-Anșārī al-Qurțubī, Al-Jāmi ‘ li Ahkām al-Qur'ān (Beirut-Lubnan: Dar al-Kutub al-'Ilmiyyah, 2006), 6: 41.
} 
SWT. Meninggalkan hukum hakam dalam al-Quran dan al-Sunnah seperti hudud dan qisas. [Kedua]: golongan kafir dari Yahudi dan Nasrani. Yahudi mengatakan 'Uzayr itu anak Allah SWT, manakala Nasrani mengatakan tuhan terdiri dari tiga, iaitu Maryam, Jibril (roh kudus) serta 'Isa. [Ketiga]: pelaku maksiat iaitu golongan yang suka melakukan maksiat dan melanggar perintahnya. [Keempat]: golongan pendusta iaitu mereka yang mendustakan syariat dan tidak mempedulikan arahan dan sunnah Nabi SAW. ${ }^{5}$

Ibn Kathīr turut menyatakan orang fasiq ialah pelaku dosa besar, pendusta dan penipu, suka menabur fitnah serta gemar melakukan kerosakan. Allah SWT melarang umat Islam mengikut jejak pelaku kerosakan. Malahan khabar yang dibawa oleh si fasiq perlu diteliti terlebih dahulu dan jangan mudah percaya. Hal ini kerana berkemungkinan besar ia terdedah kepada fitnah, penipuan dan kesalahan. ${ }^{6}$

Menurut Abū al-Haytham, "fasiq" boleh jadi "syirik (kufur)" dan boleh jadi "suka berbuat kemungkaran." Seseorang dikatakan "fasiq" jika sering melakukan maksiat, kerosakan dan melanggar aturan Allah SWT. Oleh itu, seseorang yang cenderung pada maksiat disebut fasiq. ${ }^{7}$

Berdasarkan perbincangan tersebut, penggunaan "fasiq" bagi manusia bermakna keluarnya seseorang dari jalan ketaatan kepada Allah SWT dan banyak melakukan maksiat. Manusia fasiq turut disebut sebagai "al-'Ași $\vec{\imath}$. Pengertian "fasiq" meliputi semua golongan manusia, tidak kira orang kafir, bahkan layak digelar kepada Muslim yang penipu, pendusta, pelaku mungkar dan kerosakan serta mengenepikan syariat Islam. Malahan fasiq sangat hampir kepada kekufuran.

5 'Abd al-Rahmān Muhammad Idrīs al-Rāzī Ibn Abī Ḥātim, Tafsīr al-Qur'ān al-'Azīm (Makkah-Riyadh: Maktabah Nazār Muṣțafā al-Bāz, 1997), 4:11481149.

6 'Ismā'îl Ibn Kathīr al-Dimashqī, Tafsīr al-Qur'ān al-'Azīm (Kaherah: alFarūq al-Ḥadīthiyyah li al-Tabā'ah wa al-Nashr, 2000), 13: 144-148.

7 Ibn Manẓūr, Lisān al- 'Arab, 5: 3414. 


\section{Fasiq dan Signifikannya Terhadap Haiwan}

Penggunaan "fasiq" pada haiwan bermaksud dicabut kehormatan sebahagian haiwan ${ }^{8}$ disebabkan sifatnya yang membawa datang kemudaratan, kehinaan dan kemusnahan kepada manusia. Berkaitan istilah al-dawāb iaitu haiwan melata, para ulama bersepakat penggunaan istilah ini tidak terhad kepada haiwan darat bahkan meliputi burung-burung yang terbang di awan. Ini berdasarkan dalil keumuman ${ }^{9}$ dari firman Allah SWT;

Terjemahan: "Dan tiadalah sesuatupun dari makhlukmakhluk yang bergerak di bumi melainkan Allah jualah yang menanggung rezekinya dan mengetahui tempat kediamannya dan tempat ia disimpan. Semuanya itu tersurat di dalam Kitab (Lawḥ Maḥfūụ) yang nyata."

(Surah Hud (11): 6)

Ketujuh-tujuh haiwan fasiq kesemua memiliki sifat zalim yang mengancam kesejahteraan hidup. ${ }^{10}$ Berkenaan jumlah sebenar fasiq, al-Suyuṭi telah menyatakan bahawa lima jenis haiwan fasiq yang utama iaitu tikus, kala jengking, helang, gagak dan anjing sebagaimana diriwayatkan daripada Ibn 'Umar RA tidak bermaksud ianya khusus kepada lima jenis haiwan itu sahaja. Ia hanya merupakan salah satu bentuk i'tibar (contoh) dalam menyatakan jenis haiwan fasiq dan tidak menjadi dasar ketetapan dalam hujah dan hukum hanya bagi kelima-lima jenis haiwan itu sahaja.

Kemungkinan Nabi SAW menyebutkan kelima-lima jenis haiwan ialah pada mulanya dan kemudiannya baginda SAW menyebutkan selepas itu jenis-jenis haiwan lain yang sama hukum dengan lima haiwan yang utama. Maka, bilangan "lima" haiwan fasiq tidak thābit.

Dalam sebahagian riwayat ' $\overline{\mathrm{A}}$ ' ishah RA, dinyatakan dengan lafaz "empat" dan "enam". Adapun hadith yang menyatakan

8 Muḥammad 'Abd al-Raḥmān Ibn 'Abd al-Raḥīm al-Mubārakfūrī, Tuḥfah alAḥwadhī bi Sharh Jāmi al-Tirmīdhī (t.tp.: Dār al-Fikr lil Ṭabā'ah wa alNashr wa al-Tawzī', t.t.), 3: 576.

9 Aḥmad Ibn 'Alī Ibn Hajar al-'Asqalānī, Fatḥ al-Bārī bi Sharh Șaḥịh alBukhārī (Riyadh: Fahrasah Maktabah Malik Fahd al-Wataniah Ithnā' Nashr, 2001), 4: 45.

10 Abū al-Ṭayyīb Muḥammad Shams al-Ḥaq al-'Aẓ̄m Ābādī, 'Awn al-Ma'būd Sharh Sunan Abū Dāwūd (Madinah al-Munawwarah: al-Maktabah alSalafiah, 1968), 5: 300. 
"empat" jenis haiwan fasiq yang dikeluarkan oleh Muslim riwayat al-Qāsim dari 'A' 'ishah RA dengan tidak menyebutkan gagak. Manakala "enam" jenis haiwan fasiq sebagaimana dinyatakan Muslim riwayat dari Abū 'Uwānah dari ' $\bar{A}$ 'ishah RA pula ditambah ular. Dalam hadith riwayat Abū Sa'īd al-Khuḍrī RA pula, disebutkan sebanyak "tujuh" jenis haiwan fasiq dengan tambahan " $a l-S a b$ ' $u$ al- 'A $\bar{A} \vec{\imath}$ ' iaitu haiwan buas yang biasa secara adatnya memusuhi manusia. Selain itu, dalam hadith riwayat Abū Hurayrah RA yang dikeluarkan oleh Ibn Khuzaymah, ada dinyatakan harimau dan serigala yang menjadikan "sembilan" haiwan fasiq. Hadith sama turut dikeluarkan oleh Ibn Abū Shaybah, Sa‘īd Ibn Manșūr dan Abū Dāwūd dari jalan Sa‘īd Ibn Musayyab.

Namun begitu, berkenaan empat, lima, enam atau tujuh jenis haiwan fasiq, ${ }^{11}$ hanya untuk menunjukkan persepakatan ulama tentang "illah sifat haiwan tersebut iaitu "menyakiti" ('aqūr), "tidak bermanfaat" dan "suka berbuat kerosakan" pada manusia. ${ }^{12}$

Dalam bahasa mudahnya, ia bermaksud "haiwan perosak" iaitu haiwan-haiwan yang melanggar sunnatullah sebagai makhluk yang sepatutnya tunduk kepada manusia sebagai khalifah Allah SWT bahkan menambah kemusnahan di muka bumi. ${ }^{13}$

Perkaitan tikus, cicak dan haiwan lain yang dinamakan Nabi SAW sebagai fasiq, hanya sebagai satu bentuk perumpamaan (isti'ärah) kepada aspek kemudaratan yang dibawa oleh haiwanhaiwan berikut. ${ }^{14}$ Ibn Daqīq al-' $\bar{I} d$ ada menyebutkan;

"Memperlakukan hukum tersebut (memanggil fasiq) pada semua haiwan yang mempunyai sifat "mengganggu (menyakiti manusia)" merupakan pandangan yang kuat menurut ulama berdasarkan qias. Ini jelas menurut isyarat nas

11 'Alī Ibn Ādam Ibn Mūsā al-Ityūbī al-Wallawī, Sharh Sunan al-Nas̄̄'̄̄ alMusammā Dakhīrah al- 'Uqbā fì Sharh al-Mujtabā (Riyadh: Dār al-Mi'rāj alDawliah li al-Nashr, 1996), 24: 390-391.

12 Abū 'Abd Allāh Muhammad Ibn Muhammad Ibn Yūsuf al-Sanūsī al-Hasan̄̄, Mukammil Ikmāl al-Ikmāl Sharh Ṣah̄h Muslim (Beirut-Lubnan: Dar al-Kutub al-'Ilmiyyah, t.t.), 3: 313.

13 Al-Wallawī, Sharh Sunan al-Nasā'̄ al-Musammā Dakhīrah al-'Uqbā fì Sharh al-Mujtabā, 24: 398

14 Al-Mubārakfūrī, Tuḥfah al-Aḥwadhī bi Sharh Jāmi ‘ al-Tìrmīdhī, 3: 576. 
yang membolehkan membunuh kelompok haiwan tertentu, kerana sifatnya yang fasiq, yakni melampaui batas." ${ }^{15}$

Justeru, faktor utama haiwan dikaitkan dengan istilah fasiq amat berkaitan dengan sifat "mengganggu", "mendatangkan mudarat," dan "melampaui batas" haiwan-haiwan tertentu kepada manusia. Imam al-Nawawī ada menyatakan bahawa haiwan-haiwan tertentu digelar fasiq oleh kerana keluarnya hanya mengganggu dan membuat kerosakan di jalan yang biasa dilalui haiwan tunggangan. ${ }^{16}$

\section{Perkaitan Haiwan Fasiq dengan Haiwan Perosak}

Menurut Kamus Dewan, haiwan perosak bermaksud haiwan yang merosak dan memusnahkan sesuatu benda misalnya tanaman dan harta benda manusia. Haiwan perosak juga bererti haiwan yang jahat. Manusia seperti golongan petani tidak suka dengan haiwan perosak dan ia dibunuh dengan penggunaan racun. ${ }^{17}$ Melihatkan kepada takrifan secara asas, definisi haiwan perosak adalah sama dengan haiwan fasiq.

Namun, takrifan haiwan perosak dalam Islam lebih meluas. Para ulama menggunakan istilah haiwan fasiq kerana disabdakan Nabi SAW. Kelompok haiwan fasiq tidak terhad kepada haiwan yang disebutkan dalam riwayat sahaja (Iaitu tikus, kala jengking, gagak, helang, cicak, ular dan anjing). Mereka turut memasukkan spesies haiwan lain seperti lipan, serigala dan harimau malah semua haiwan yang bersifat memusuhi manusia atau haiwan ternakan, menjejaskan kesihatan atau hasil tanaman dalam kategori "haiwan fasiq". Pendapat ini juga disokong oleh para pendokong mazhab Syafie, Maliki, Hanafi dan Hanbali. ${ }^{18}$

Oleh itu, para ulama turut bersepakat bahawa gelaran tikus sebagai fasiq untuk mengisyaratkan gelaran "fasiq" kepada semua haiwan yang mengganggu manusia dengan cara merosak dan

15 Ibn Hajar, Fath al-Bari bi Sharh Sahih al-Bukhari, terj. Amiruddin et al., 10: 208.

16 Yaḥyā Ibn Sharf al-Nawāwī, Al-Minhāj Sharh Ṣaḥịh Muslim (Mesir: Dār Ihyā' al-Turāth al-'Arabī, 1930), 14: 97.

17 Kamus Dewan Online, laman sesawang Pusat Rujukan Persuratan Melayu (PRPM), dicapai pada 20 September http://prpm.dbp.gov.my/Search.aspx?k=haiwan+perosak

18 Ibn Hajar, Fath al-Bari bi Sharh Sahih al-Bukhari, terj. Amiruddin et al., 10: 207-208. 
memotong-motong sesuatu. Penyebutan gagak dan helang untuk mengisyaratkan semua haiwan yang mampu mengganggu manusia dengan menyambar seperti helang dan bersikap pengotor seperti gagak pemakan bangkai.

Manakala permisalan anjing 'aqur menunjukkan sifat fasiq haiwan yang menyerang dengan gigitan taringnya seperti serigala dan singa. ${ }^{19}$ Sebutan " aqrab" (kala jengking) untuk menunjukkan semua haiwan yang mengancam melalui gigitan beracun seperti ular, lipan, lebah dan sebagainya. Kesimpulannya, semua haiwan yang memiliki sifat-sifat yang ditonjolkan ketujuh-tujuh jenis haiwan fasiq adalah tergolong dalam kalangan haiwan yang harus dibunuh jika berbahaya dan terdapat ancaman. ${ }^{20}$

Haiwan perosak mempunyai persamaan dengan haiwan fasiq dari aspek menghadirkan mudarat, gangguan dan ancaman kepada manusia, haiwan ternakan, harta benda dan hasil tanaman. Justeru, istilah haiwan perosak tidak berbeza dengan haiwan fasiq. Haiwan fasiq hanyalah istilah perumpamaan baginda SAW dalam memberi panduan untuk menentukan haiwan yang melampaui batas dan harus dihindari demi memelihara agama, nyawa, akal, harta benda dan keturunan umat Islam. ${ }^{21}$

Daripada perbahasan tersebut, kelompok haiwan fasiq seperti ular, tikus, helang, cicak, kala jengking, anjing dan ular merupakan haiwan yang mempunyai tabiat buruk dan merbahaya. Setiap haiwan membawa motif dan kerosakan berbeza. Islam membolehkan kelompok haiwan fasiq dibunuh kerana kefasikannya (sifat melampaui batas) yang mendatangkan kesan negatif terhadap manusia.

19 Ibn Hajar, Fath al-Bari bi Sharh Sahih al-Bukhari, terj. Amiruddin et al., 10: 208-209.

20 Monika@Munirah Abd Razak, Nik Mohd Zaim Ab Rahim, "Hadith-Hadith Mengenai Anjing: Tumpuan Kepada Isu Pemeliharaan dan Pengharamannya daripada Perspektif Hadith Ahkam," dalam Seminar Antarabangsa Sunnah Nabawiyyah: Realiti dan Cabaran Semasa (MUSNAD I), ed. Fauzi Deraman, Ishak Suliaman dan Faisal Ahmad Shah, Jabatan al-Quran \& al-Hadith, Akademi Pengajian Islam, Universiti Malaya, 2011), 526-532.

21 Al-Mubārakfūrī, Tuḥfah al-Aḥwadhī bi Sharḥ Jāmi ‘ al-Tirmìdhī, 3: 576. 


\section{Ulasan Fiqh al-Hadīth Mengenai Ular Sebagai Haiwan Perosak \\ Ular dan Sifatnya}

Terjemahan: Dari 'A' 'ishah RA, Sesungguhnya Rasulullah SAW pernah bersabda: "Ular itu fasiq, kala jengking itu fasiq, tikus itu fasiq dan gagak itu fasiq. Setelah itu, al-Qāsim ada ditanya oleh seseorang: "Bolehkah gagak dimakan?" maka al-Qāsim pun menjawab: "Siapa yang mahu memakannya setelah Rasulullah SAW menggelarnya fasiq (jahat)?"22

Ular merupakan haiwan menggerunkan dengan bisa dan gigitan berbahaya yang mampu mengundang maut. ${ }^{23}$ Ular terdiri daripada pelbagai jenis dengan ada yang memiliki bisa, ada yang menggigit dan membelit dilengkapi gigi tajam serta tubuh berotot yang kuat. Memelihara ular adalah perkara yang tidak disukai syara' tanpa ada keperluan.

Terjemahan: Dari Ibn 'Umar RA: dia mendengar Nabi SAW berkhutbah di atas mimbar. Baginda SAW bersabda: "Bunuhlah ular dan bunuhlah dhä al-Tifyatayn dan al-Abtar, kerana keduanya berupaya merosakkan penglihatan dan menggugurkan kandungan."

(Hadith riwayat al-Bukhārī) $^{24}$

Berkenaan sifat dua jenis ular berbahaya dalam hadith berikut, "dha al-Tifyatayn" (ular yang memiliki dua garis putih di belakang) ${ }^{25}$ dan "al-Abtar" (ular yang berekor pendek), ${ }^{26}$ ancamannya sama dengan ancaman ular masa kini misalnya tedung selar, ular kapak dan ular sawa. Semuanya berbahaya, boleh membunuh dalam masa singkat, membutakan penglihatan

22 Hadith riwayat Ibn Mājah, Kitab al-Șīd, Bāb al-Ghurāb, no. Hadith 3249. Lihat Ibn Mājah al-Qazwaynī, Sunan Ibn Mājah (Riyadh: Maktabah alMa‘ārif li al-Nashr wa al-Tawzī’, 1986), 548.

23 Al-Wallawī, Sharh Sunan al-Nasā'̄̄ al-Musammā Dakhīrah al-'Uqbā fì Sharh al-Mujtabā, 24: 405.

24 Hadith riwayat al-Bukhārī, Kitāb Bad' al-Khalq, Bāb Qawl Allāh wa Baththa fīhā min kulli Dābbah, no. Hadith 3297. Lihat Abū 'Abd Allāh Muhammad Ibn Ismā'īl al-Bukhārī, Al-Jāmi ‘ al-Sạh̄̄h al-Musnad min Hadīth Rasūl Allāh wa Sunanih wa Ayyāmih (Kaherah: Al-Maktabah al-Salafiyyah wa Maktabatuhā, 1980), 2: 443

25 Abū Sulaymān Muhammad Al-Khaț̣abī al-Bustī, Ma ālim al-Sunan Sharh Sunan Abū Dāwūd (Halab: Matba'ah al-'Ilmiyyah, 1934), 4: 157.

26 Al-Khaț̣abī, Ma'àlim al-Sunan Sharh Sunan Abū Dāwūd, 4: 157 
dan menggugurkan kandungan dengan patukan bisa dan lilitannya.

\section{Hukum Membunuh Ular}

Terjemahan: Dari Abū Hurayrah RA, Raslullah SAW bersabda; "Kami tidaklah berdamai dengan mereka (ular) sejak kami memerangi mereka, barang siapa meninggalkannya kerana takut (gigitan dan patukan), maka bukan dari golongan kami."

$$
\text { (riwayat Abu Dawud) }^{28}
$$

Menurut Ibn Mundhīr, para ulama mengharuskan membunuh semua spesies ular berdalilkan nas tersebut. Imam al-Bukhari turut menyatakan membunuh ular dalam dan luar tanah Haram tidak dilarang. Akan tetapi, pendapat ini dikritik Imam Malik, Hammad dan al-Hakam yang mengecualikan membunuh ular kecil yang belum mampu menghadirkan bahaya. ${ }^{29}$

Bagi ular yang menghuni rumah, larangan Nabi SAW dari membunuhnya berdasarkan riwayat Abu Lubabah RA adalah demi menjaga maslahah kaum jin agar tidak dibunuh sewenangwenangnya. Boleh jadi ular tersebut merupakan jelmaan jin. Ini berdasarkan hadith;

Terjemahan: Dari Ibn 'Umar RA, sesungguhnya dia (Ibn 'Umar RA) telah membunuh ular-ular (yang ditemuinya), maka diceritakan kepadanya akan satu sabda Nabi SAW dari Abu Lubabah RA; "Sesungguhnya Nabi SAW melarang (setelah itu) membunuh jin-jin yang (menyerupai ular) yang menghuni rumah-rumah manusia."

$\left(\right.$ Hadith riwayat al-Bukhārīi) ${ }^{30}$

27 Al-Nawāwī, Al-Minhāj Sharh Șah̄ịh Muslim, 14: 230

28 Hadith riwayat Abū Dāwūd, Kitāb al-Ādāb, Bāb fī Qatl al-Hayāh, no. Hadith 5248. Lihat Abū Dāwūd Sulaymān Ibn al-Ash'ath al-Sajistān̄i, Sunan Abū Dāwūd (Riyadh: al-Maktabah al-Ma'ārif li al-Nashr wa al-Tawzī’, 1988), 948.

29 Ibn Hajar, Fath al-Bari bi Sharh Sahih al-Bukhari, terj. Amiruddin et al., 10: 210

30 Hadith riwayat al-Bukhārī, Kitab Bad' al-Khalq, Bab Khayr al-Māl Muslim Ghanam Yattabi' bihā Sha'fu al-Jabāl, no. Hadith 3313. Lihat Abū 'Abd Allāh Muḥammad Ibn Ismā'īl al-Bukhārī, Al-Jāmi' al-Ṣaḥịh al-Musnad min Hadìth Rasūl Allāh wa Sunanih wa Ayyāmih, 2: 446. 
Dalam mengenal rupa ular jelmaan jin, Ibn Ḥajar al-'Asqalānī ada menyebutkan bahawa ular jelmaan jin berbentuk kecil halus dan dikatakan ada yang berwarna putih. ${ }^{31}$ Hal ini kerana jin dianugerahi Allah SWT dengan kelebihan dapat menjelma dalam bentuk seperti ular, kala jengking, anjing bahkan mampu menyerupai manusia. Nabi SAW juga pernah bersabda;

Terjemahan: Dari Abū Tha'labah RA berkata, aku mendengar Rasulullah SAW bersabda: "Jin mempunyai tiga jenis, satu jenis yang berbentuk anjing dan ular, satu jenis lagi yang mempunyai sayap berterbangan di udara, dan jenis (seterusnya ialah) yang berpindah randah."

(Hadith riwayat Ibn Hibbān) $^{32}$

Namun begitu, ia boleh dibunuh jika tetap berdegil, enggan keluar dan masih mengganggu selepas diberi peringatan (indhar). Nabi SAW telah mengajarkan doa untuk memohon perlindungan dan memberi peringatan pada ular yang menghuni rumah iaitu; ${ }^{33}$

Terjemahan: Dari 'Abd al-Rahman Ibn Abū Laylā berkata, telah berkata Abū Laylā RA (Dāwūd Ibn Bilāl), Rasulullah SAW bersabda; "Apabila muncul ular di rumah kamu, maka katakan kepadanya, "Aku memohon (berlindung) daripadamu dengan (perjanjianmu pada) Nabi Nūh AS dan Nabi Sulaymān Ibn Dāwūd AS (kepadamu) agar tidak menyakiti (mengganggu) kami." Jika ia kembali (mengganggu), maka bunuhlah ia.

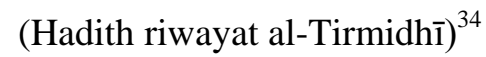

Terjemahan: Rasulullah SAW telah ditanya tentang ular yang menghuni rumah manusia: baginda SAW bersabda: "Jika

\footnotetext{
31 Al-'Asqalānī, Fath al-Bārī bi Sharh Sahīh al-Bukhārī, 6: 408.

32 Sahīh Ibn Hibbān, Kitab al-Tarīkh, Bāb Bad' al-Khalq, Dhikr Wașf Ajnās alJān allatī 'alayhā Khuliqat, no. Hadith 6156. Lihat 'Alī Ibn Bilbān al-Fārisī, Șạ̄ḥ Ibn Hibbān bi Tartīb Ibn Bilbān (Beirut: Muassasah al-Risalah, 1993), 14: 26. Dinilai Șahīḥ oleh al-Albānī.

33 Al-Qāḍī 'Iyāḍ, Sharh Șah̄h Muslim li al-Qāḍ̄ 'Iyāẹ al-Musamma Ikmal Mu'allim bi Fawā'id Muslim (Mansurah: Dār al-Wafă' li al-Ṭaba'ah wa alNashr wa al-Tawzī‘, 1998), 7: 167.

34 Hadith riwayat al-Tirmidhī, Kitab al-al-Ṣīd, Bāb Mā Jā'a fĩ Qatl al-Hayāt, no. Hadith 1485. Lihat Abū 'Abd 'Allāh Abū 'Īsā al-Tirmidhī, Sunan al-Tirmidhi (Riyadh: Maktabah al-Ma'ārif li al-Nashr wa al-Tawzī‘ , 1996), 352. Namun begitu, hadith ini dinilai dhaif oleh Albānī disebabkan terdapat Ibn Abū Lailā (Muḥammad Ibn 'Abd al-Raḥmān Ibn Yasār) yang dikritik sebagai da'îf alhadīth dalam rangkaian sanad.
} 
salah seorang dari kalian melihat ular berada di rumah-rumah kamu, maka katakanlah kepada mereka; "Aku sumpah kamu dengan janji kamu kepada Nuh AS, aku sumpah kamu dengan janji kamu kepada Sulayman AS, yakni agar kamu tidak mengganggu kami." Jika mereka tetap kembali maka bunuhlah mereka.

(Hadith riwayat Abū Dāwūd) ${ }^{35}$

Dalam bab memberi peringatan (indhār) pada ular yang menghuni dalam rumah supaya keluar, ulama berselisih pendapat berkenaan tempoh tersebut sama ada tiga hari atau tiga kali.

Terjemahan: Dari Abū Sa'īd al-Khudrī RA, Rasulullah SAW bersabda: "Sesungguhnya di wilayah Madinah ini ada sekumpulan jin yang telah memeluk Islam, jika kamu melihat sesuatu yang pelik padanya, maka izinkanlah ia tinggal selama tiga (hari), jika ia masih ada (selepas itu), maka bunuhlah ia oleh kerana itu adalah syaitan."

$$
\text { (Hadith riwayat Muslim) }^{36}
$$

Dalam riwayat lain, disebutkan ular yang tidak mahu keluar dari rumah setelah indhār sebanyak tiga kali merupakan syaitan dan boleh dibunuh iaitu;

Terjemahan: Dari Abū Sa‘īd al-Khudrī RA, Rasulullah SAW bersabda: "Sesungguhnya ular hitam itu adalah jin, maka sesiapa yang melihatnya di rumah, berilah ia peringatan sebanyak tiga kali, jika ia kembali, maka bunuhlah ia kerana itu adalah syaitan."

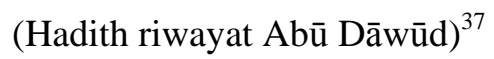

35 Hadith riwayat Abū Dāwūd, Kitāb al-Ādāb, Bāb fì Qatl al-Hayāt, no. Hadith 5260. Lihat Abū Dāwūd Sulaymān Ibn al-As'ath al-Sajistān̄̄, Sunan Abū Dāwūd (Riyadh: al-Maktabah al-Ma‘ārif li al-Nashr wa al-Tawz’̄', 1988), 950. Namun begitu, hadith ini dinilai dhaif oleh Al-bānī disebabkan terdapat Ibn Abū Laylā (Muḥammad Ibn 'Abd al-Raḥmān Ibn Yasār) yang dikritik sebagai ḍa'îf al-ḥadīth dalam rangkaian sanad.

36 Hadith riwayat Muslim, Kitab al-Salām, Bāb Qatl al-Hayāt wa Ghayrihā, no. Hadith 5841. Lihat Abū al-Husāyn Muslim Ibn al-Hajjāj al-Qushayrī alNaysabūrī, "Șahịḥ Muslim," dalam Mawsū'at al-Hadìth al-Sharīf al-Kutub al-Sittah, ed. Șāliḥ Ibn 'Abd al-Azīz Āl al-Shaykh (Riyadh: Dār al-Salām li al-Nashr wa al-Tawzī', 2000), 1075.

37 Hadith riwayat Abū Dāwūd, Kitab al-Ādāb, Bāb fì Qatl al-Hayāt, no. Hadith 5256. Lihat Abū Dāwūd, Sunan Abū Dāwūd, 949-950. 
Kesimpulannya, jumhūr ulama' memilih pendapat yang lebih kuat iaitu tiga hari. ${ }^{38}$ Indhār merupakan perkara yang penting. Abū Sa 'īd al-Khudrī RA pernah menceritakan kisah seorang pemuda yang mati selepas terus membunuh ular yang berada dalam rumahnya;

Terjemahan: Dari Abū al-Sā'ib, aku pernah menjenguk Abū Sa'īd al-Khuḍrī RA di rumahnya. Lalu aku mendapatinya sedang solat. Maka aku pun duduk menunggunya. Setelah selesai solat, aku mendengar suara di salah satu tiang atap rumah. Aku melihat dan ternampak seekor ular. Maka aku pun bangkit hendak membunuhnya. Namun Abu Sa'id alKhudri RA mengisyaratkan agar aku duduk kembali. Aku pun duduk. Setelah keluar, beliau menunjuk ke arah sebuah rumah. Beliau bertanya, "Apakah engkau melihat rumah itu?" "Ya!" jawabku. Beliau bercerita, "Dahulu di rumah itu tinggal seorang pemuda yang baru sahaja berkahwin. (Tidak lama kemudian), kami (bersamanya) berangkat bersama Rasulullah SAW ke peperangan Khandaq. (Namun) pemuda itu meminta izin kepada Rasulullah SAW untuk kembali ke rumahnya pada waktu tengah hari. Rasulullah SAW mengizinkannya dan berkata kepadanya, "Bawalah senjatamu, aku khuatir engkau diganggu oleh Bani Qurayzah. Maka pemuda itu pun membawa senjatanya. Kemudian dia kembali ke rumahnya. Sesampainya di rumah, dia mendapati isterinya berdiri di hadapan pintu rumahnya. Maka ia pun menyerbu ke arah isterinya untuk memukulnya oleh kerana cemburu. Lantas si isteri berkata kepadanya; "Tunggu dahulu! Masuklah ke dalam rumah supaya engkau dapat melihat apa yang menyebabkan aku keluar." Maka pemuda itu pun masuk ke dalam rumah dan mendapati ular besar melingkar di atas katil. Dia pun menyerang ular tersebut dengan tombaknya. Kemudian dia keluar sedang ular tersebut pada hujung tombaknya. Lalu ular itu menggeliat dan menyerangnya. Namun, tidak diketahui siapakah yang lebih dahulu mati apakah ular itu atau pemuda tadi. Kami pun menceritakan peristiwa itu kepada Rasulullah SAW dengan berkata; "Mohonlah kepada Allah SWT agar dihidupkannya

38 Abū al-Ṭayyīb Muḥammad Shams al-Ḥaq al-'Aẓīm Ābādī, 'Awn al-Ma 'būd Sharh Sunan Abū Dāwūd, 14: 164. 
kembali." Rasulullah SAW bersabda; "Mohonlah ampun untuk sahabat kamu." Kemudian baginda bersabda lagi; "Sesungguhnya kota Madinah dihuni oleh jin-jin Islam. Jika kalian melihat mereka dalam bentuk ular, maka usirlah selama tiga hari. Jika masih kelihatan, bunuhlah kerana itu adalah syaitan."

(Hadith riwayat Muslim) $^{39}$

Bagi ular di luar rumah, tidak perlu diberi peringatan terlebih dahulu dan diharuskan membunuhnya bertujuan untuk menolak kemudaratan sekalipun di masjid-masjid. ${ }^{40}$ Selanjutnya, alMaziri $^{41}$ dan Imam Malik berpendapat indhār hanya khusus dilakukan terhadap ular di tanah Madinah. Manakala ular di tempat lain tidak perlu diberi peringatan terlebih dahulu bahkan sunat dibunuh berlandaskan keumuman hadith riwayat Ibn Mas'ud yang menyuruh membunuh tanpa menyebutkan indhār. ${ }^{42}$

Terjemahan: Dari Ibn Mas'ud RA berkata: Rasulullah SAW bersabda: "Bunuhlah ular keseluruhannya, sesiapa yang takut akan kesannya (gigitan dan patukan), maka ia bukan dari golongan kami."

(Hadith riwayat Abū Dāwūd) ${ }^{43}$

Namun begitu, pengarang kitab 'Awn al-Ma'būd berpandangan pendapat paling rājih ialah perintah memberi peringatan pada ular (indhār) merupakan perintah umum, bukannya khusus kepada ular di Madinah dan terpakai di semua tempat. ${ }^{44}$

Bagi spesies ular berbahaya seperti al-Tifyatayn, al-Abtar dan seumpama, Mālik, al-Qāọī 'Iyāọ dan sebahagian ulama bersepakat

39 Hadith riwayat Muslim, Kitab al-Salām, Bab Qatl al-Hayāt wa Ghayrihā, no. Hadith 5839. Lihat Abū al-Husayn Muslim Ibn al-Hajjāj al-Qushayrī alNaysabūrī, "Șah̄ịh Muslim," dalam Mawsū'at al-Hadìth al-Sharīf al-Kutub al-Sittah, ed. Șāliḥ Ibn 'Abd al-'Azīz Āl al-Shaykh (Riyadh: Dār al-Salām li al-Nashr wa al-Tawzī', 2000), 1075.

40 Yahyā Ibn Sharf al-Nawāwī, Al-Minhāj Sharh Ṣah̄̄h Muslim, 14: 234.

41 Al-Māzirī atau nama penuhnya Abū 'Abd Allāh Muhammad Ibn 'Alī Ibn 'Umar al-Tamīmī al-Māzirī al-Malikī. Beliau lahir pada 453H dan wafat pada 536H. Beliau merupakan tokoh ulama fiqh bermazhab Maliki.

42 Al-Nawāwī, Al-Minhāj Sharh Șahīh Muslim, 14: 230

43 Hadith riwayat Abū Dāwūd, Kitāb al-Ādāb, Bāb fĩ Qatl al-Hayāt, no. Hadith 5249. Lihat Abū Dāwūd, Sunan Abū Dāwūd, 949.

44 Abū al-Ṭayyīb Muḥammad Shams al-Ḥaq al-'Aẓ̄m Ābādī, 'Awn al-Ma 'būd Sharh Sunan Abū Dāwūd, 14: 164 
spesies tersebut tidak tergolong dalam hukum ular penghuni rumah ('awāmir), bahkan boleh dibunuh tanpa indhār jika berada di dalam rumah apatah lagi di luarnya disebabkan ia merupakan spesies merbahaya dan bukan dari jelmaan jin. ${ }^{45}$

\section{Teknik Kawalan Terhadap Haiwan Fasiq (Haiwan Perosak) Menurut Fiqh al-Hadīth}

Mengenal haiwan fasiq dan jenis seumpamanya merupakan piawaian utama. Haiwan fasiq (haiwan perosak) dikenalpasti berasaskan empat kriteria utama iaitu:

Pertama; Haiwan yang mengganggu kesejahteraan hidup (melampaui batas).

Kedua; Haiwan yang mengancam nyawa dan kesihatan.

Ketiga; Haiwan yang merosakkan harta benda (membuat kemusnahan dan kerosakan).

Keempat; Haiwan yang mengancam haiwan ternakan dan tanaman.

Memahami sifat-sifat haiwan fasiq, membolehkan langkah mengenalpasti, mencegah dan menangani ancaman kelompok haiwan perosak dan seumpama dapat dilakukan secara berkesan. Ini sekaligus mengelakkan sebarang kekeliruan yang boleh mengakibatkan pembabitan haiwan yang tidak terlibat.

\section{Kaedah Membunuh Haiwan Perosak}

Metode terbaik dalam berinteraksi dengan kelompok haiwan fasiq (haiwan perosak) sekaligus menghilangkan mudaratnya pada manusia ialah dengan cara membunuh. Malah, gelaran fasiq terhadap haiwan itu sendiri telah menjadikannya harus dibunuh. Hal ini berlandaskan kaedah fiqh al-Darar Yuzal, iaitu kemudaratan mesti dihapuskan.

Islam menganjurkan umatnya menggunakan cara paling ihsan dalam melaksanakan pembunuhan. Cara terbaik untuk membunuh kelompok haiwan tersebut ialah dengan satu pukulan yang terus mematikan. Hal ini dikiaskan dari cara membunuh cicak yang diajarkan Nabi Muhammad SAW. Sekaligus mengelakkan haiwan tersebut terseksa menanggung kesakitan sementara menunggu pukulan kedua. Ini berdasarkan hadith;

45 Ibn Hajar al-'Asqalānī, Fatḥ al-Bārī bi Sharh Șaḥịh al-Bukhārī, 6: 408. 
Terjemahan: Dari Abu Hurayrah RA, Rasulullah SAW bersabda, "Sesiapa yang membunuh seekor cicak dengan sekali pukulan maka baginya sekian-sekian kebaikan. Dan sesiapa yang membunuhnya dengan dua pukulan maka baginya sekian-sekian kebaikan, kurang dari yang pertama tadi. Dan jika sesiapa dapat membunuhnya dengan tiga pukulan maka baginya sekian-sekian kebaikan, kurang dari yang kedua tadi."

(Hadith riwayat Muslim)

'Iz al-Dīn Ibn 'Abd al-Salam turut menyebutkan membunuh dengan pukulan pertama merupakan kaedah terbaik bahkan menepati maqasid hadith Nabi SAW berikut;

Terjemahan: Dari Shaddad Ibn Aws RA, sesungguhnya Nabi SAW bersabda, "Sesungguhnya Allah SWT telah mewajibkan ihsan kepada semua perkara. Jika kamu membunuh, maka perelokkan pembunuhan kamu."

(Hadith riwayat Muslim)

Mengulas cara paling tepat membunuh haiwan fasiq, harus diteliti pada tindakan Saidatina ' $\bar{A}$ 'ishah RA. Beliau menggunakan tombak dan lembing untuk membunuh cicak.

Terjemahan: Dari Sa'īd Ibn al-Musayyib RA, ada seorang perempuan (Ummu Sharik) datang kepada ' $\bar{A}$ ' ishah RA dan di tangannya ada lembing. Maka ' $\bar{A}$ 'ishah bertanya: Untuk apakah lembing ini? Ummu Sharik pun menjawab: Untuk membunuh cicak. "Sesungguhnya Nabi SAW telah menceritakan saat Nabi Ibrahim AS ketika dicampakkan ke dalam api, tiada seekor pun haiwan yang tidak cuba memadamkan api yang sedang membakar kecuali cicak, maka Nabi SAW memerintahkan agar membunuhnya."

(Hadith riwayat al-Nasa'i)

Terjemahan: Dari Sa'ibah Mawlah al-Fakih Ibn al-Mughīrah bahawasanya dia menemui ' $\bar{A}$ 'ishah RA dan melihat di dalam rumahnya terdapat sebuah tombak. Dia pun bertanya kepada 'Ā'ishah RA: "Wahai Ummu al-Mu'minin, apa yang engkau lakukan dengan tombak ini? ' $\bar{A}$ 'ishah RA menjawab: "Untuk kami membunuh cicak-cicak. Sesungguhnya Nabi SAW pernah memberitahu kami bahawa tatkala Ibrahim AS dilemparkan ke dalam api tidak ada satu pun haiwan di bumi saat itu kecuali dia akan memadamkannya kecuali cicak yang 
meniup-niupkan apinya. Maka Rasulullah SAW
memerintahkan agar membunuhnya."

(Hadith riwayat Ibn Majah)

Ini dilakukan agar urusan pembunuhan menjadi lebih baik sebagaimana dikiaskan dari penggunaan pisau tajam untuk menyembelih haiwan sembelihan agar tidak menyeksakan dan kurang mendatangkan kesakitan.

Selanjutnya, Islam melarang membunuh haiwan dengan cara membakar, melemas, merejam, memberi makanan beracun atau cara lain berasaskan kekejaman. Ini berpandukan hadith;

Terjemahan: Dari Abu Hurayrah RA, Rasulullah SAW bersabda; "Seorang nabi daripada nabi-nabi telah duduk di bawah sebatang pokok, dan seekor semut betina menggigitnya, maka baginda telah memerintahkan pengikutnya supaya keluar dari (kawasan) bawah pokok tersebut. Kemudian baginda memerintahkan supaya dibakar seluruh sarang semut tersebut dengan api, maka Allah SWT mewahyukan kepadanya: Adakah hanya kerana seekor semut betina?"

(Hadith riwayat al-Bukhārī)

\section{Kaedah Memukul dan Menyembur Racun Pada Muka Haiwan Perosak}

Terjemahan: Dari Jabir RA berkata: "Rasulullah SAW melarang memukul haiwan pada bahagian muka dan menyembur racun pada mukanya."

(Hadith riwayat Muslim)

Mengulas nas berikut, memukul haiwan pada bahagian muka adalah dilarang kerana kepala merupakan anggota tubuh yang lembut dan sensitif. Ijma' ulama turut mengharamkan semburan racun pada muka haiwan berdarah (al-Adami) seperti keldai dan unta kerana menyeksa haiwan. Dalam riwayat lain, baginda SAW pernah melaknat orang yang meracun himar (keldai) pada wajahnya.

Bagi perbuatan menyembur racun pada wajah haiwan tidak berdarah (ghayr al-Adami) seperti semut dan kala jengking, Imam al-Nawawi menghukum makruh perbuatan tersebut. Al-Baghawi pula tetap tidak membolehkannya, dengan merujuk kepada laknat Nabi SAW yang menunjukkan pengharaman sesuatu perbuatan. 
Kesimpulannya, menyembur racun pada muka haiwan berdarah (al-Adami) adalah haram. Semburan racun yang diharuskan Islam hanya pada anggota selain dari muka. Misalnya pada belakang badan unta dan lembu bertujuan membezakan haiwan ternakan. Inilah pegangan sahabat RA dan jumhur ulama. Namun, Imam Abu Hanifah tetap tidak membolehkannya dan menghukum makruh kerana menyeksakan haiwan.

Sebaiknya, penggunaan racun untuk menangani ancaman haiwan fasiq jenis berdarah (al-Adami) perlu dielakkan. Kaedah seperti menembak dan memukul lebih berkesan terhadap kelompok tersebut. Hal ini kerana racun boleh memberi kesan buruk yang menyeksakan dengan cara meresap ke dalam saluran darah dan merosakkan organ dalaman haiwan.

Bagi haiwan tidak berdarah (ghair al-Adami), menyembur racun pada bahagian selain muka adalah harus. Jika menyembur racun pada bahagian muka, hukumnya makruh dan tidak sampai kepada hukum haram. Ini mengambil kira pandangan Imam alNawawi dan kesulitan dalam menangani ancaman haiwan fasiq tidak berdarah (ghair al-Adami) yang kecil, licik dan sukar ditentukan bahagian yang ingin disembur racun.

\section{Kaedah Pemindahan dan Pemusnahan Habitat Haiwan Perosak}

Habitat haiwan fasiq (haiwan perosak) yang tinggal jauh dari manusia seperti kala jengking, ular, helang dan seumpama tidak boleh dimusnahkan. Hal ini kerana ia menjadi tempat tinggal anak-anak haiwan terbabit yang terkecuali dari hukum haiwan fasiq. Haiwan jenis ini lebih tertumpu mencari mangsa untuk dimakan, bersifat mementingkan kawasan dan jarang mengganggu manusia melainkan diancam atau kawasannya telah diceroboh.

Bagi spesies haiwan fasiq (haiwan perosak) yang tinggal di dalam atau berhampiran persekitaran manusia sehingga menghadirkan gangguan dan ancaman seperti tikus, gagak, anjing dan cicak. Habitat tersebut wajib dimusnahkan dan anak-anaknya perlu dibunuh atau dipindahkan dari penempatan manusia. 


\section{Kaedah Efektif Kontemporari Selaras dengan Tuntutan Syara'}

Bagi haiwan fasiq yang lebih besar dan tidak mungkin mati dengan satu pukulan seperti anjing, cara lain adalah diharuskan seperti menembak, memasang jerat, perangkap dan penggunaan pagar elektrik harus dilakukan jika berkesan menghindarkan gangguan makhluk perosak dengan syarat tiada unsur penyeksaan dan ikhlas kerana Allah SWT.

Metode lain adalah harus dilaksanakan sesuai dengan kemajuan teknologi semasa. Prinsip utama dalam interaksi dengan haiwan fasiq (haiwan perosak) mestilah dijaga, iaitu membunuh bukan sekadar suka-suka, tetapi atas dasar maslahah, ikhlas dalam perbuatan, tidak mengandungi unsur penyeksaan dan penganiayaan haiwan serta efektif. Islam mengutuk perbuatan membunuh mana-mana haiwan tanpa keperluan. Ini dijelaskan hadith,

Terjemahan: Dari 'Amru Ibn al-Sharid berkata, aku mendengar al-Sharid RA berkata: Aku mendengar Rasulullah SAW bersabda: "Barangsiapa membunuh burung sia-sia, maka ia akan mengadu di hadapan Allah SWT nanti dengan berkata: "Ya Allah ya tuhanku, si fulan telah membunuhku sia-sia."

(Hadith riwayat al-Nasa'i)

\section{Teknik Kawalan Umum Terhadap Ular}

Di Malaysia, spesies ular hari ini semakin diancam kepupusan dan ia termasuk dalam senarai hidupan liar yang dilindungi. Antara spesies ular yang dilindungi di Malaysia ialah ular Sawa (phyton reticulatus), ular Senduk Asia (naja naja), ular Tedung Selar (ophiophagus hannah), ular Pantai Belang (maticora intestinalis), ular Pantai Bintik (calliophis gracilis), ular Pantai Bintik Kecil (calliophis maculiceps), ular Katam Tebu (bungaris candidus), ular Katam Belang (bungarus fasciatus), ular Katam Kepala Merah (bungarus flaviceps), ular Pantai Biru-Biru (maticora bivirgata), ular Kapak Sumatera (trimeresurus sumatranus), ular Kapak Ekor Merah (trimeresurus popeiorum), ular Kapak Tokong (tropidolaemuss wagleri), ular Kapak Gunung (ovophis monticola convictus), ular Kapak Bodoh (calloselasma rhodostoma), ular Kapak Bakau (trimeresurus purpureomaculatus) dan ular Kapak 
Hidung Pipih (trimeresurus puniceus) (Akta Pemuliharaan Hidupan Liar 2010, Pindaan 2012).

Sehubungan itu, teknik kawalan seperti membunuh, menembak, memukul, meracun dan semua kaedah yang didapati mengancam kemandirian spesies ular adalah salah dari sisi undang-undang Malaysia. Bahkan untuk memerangkap dan menjerat ular memerlukan permit khas. Hal ini perlu demi mengelakkan kepupusan haiwan sekaligus mengekalkan kestabilan ekosistem. Malahan terdapat pelbagai cara lain yang boleh dipraktikkan bagi menghindari ancaman dan gangguan ular. Antaranya pendekatan menghindari ancaman dan gangguan ular adalah:

Pertama; Pastikan kawasan kediaman, kebun, kawasan pertanian dan kawasan pemeliharaan haiwan ternakan sentiasa dalam keadaan bersih. Ular sukakan kawasan yang kotor dan penuh dengan sampah sarap. Hal demikian kerana kawasan sedemikian kebiasaanya dihuni oleh makluk perosak seperti tikus. Kehadiran tikus dalam sesuatu kawasan akan menarik perhatian pemangsanya iaitu ular mendekati kawasan tersebut.

Kedua; Mengambil langkah berjaga-jaga apabila memasuki tempat yang tersembunyi, gelap, sejuk dan lembap kerana ular sukakan tempat sedemikian sebagai tempat perlindungan. Berhatihati apabila memasuki tandas, dapur dan tempat-tempat yang berpotensi didiami oleh ular. Jangan sekali-kali memasukkan tangan atau kaki ke tempat yang mana dipercayai terdapat ular seperti di celah batu, di bawah tunggul kayu dan sebagainya, sekiranya perlu gunakan kayu terlebih dahulu.

Ketiga; Memelihara haiwan pemangsa kepada ular. Burung helang adalah haiwan pemangsa yang tertinggi dalam siratan makanan haiwan. Pendekatan membela burung helang sebagai penjaga dalam kawasan pertanian adalah langkah bijak bagi menjaga kawasan tersebut daripada pencerobohan tikus dan ular.

Keempat; Meningkatkan aktiviti manusia di sekitar kawasan haiwan ternakan. Kebiasaannya, ular tidak akan menyerang manusia, malah ular sebenarnya takut kepada manusia. Kebanyakan kes gigitan ular terjadi apabila ular terkejut, terpijak ataupun tempat kediamannya diganggu oleh manusia sama ada secara sengaja ataupun tidak. Sekiranya terserempak dengan sekumpulan ular, jangan menghampirinya kerana mungkin ketika 
itu musim mengawan dan kebanyakan ular amat agresif pada masa tersebut. Elakkan juga daripada cuba menangkap ular atau mengganggu ular tersebut.

\section{Penutup}

Islam bukanlah agama yang menganjurkan kekejaman dan menafikan hak haiwan untuk hidup. Islam meraikan hak dan keperluan semua pihak selagi mana ia tidak melampaui batas. Selagi mana haiwan itu hidup, Islam meraikan kewujudannya. Begitu juga ketika mahu dicabut nyawanya, Islam mengajarkan cara yang paling ihsan untuk melakukannya. Hal ini perlu difahami dengan baik untuk mengelakkan sebarang bentuk salah faham terhadap Islam.

Rasulullah SAW telah memperingatkan akan potensi ancaman yang mampu dihadirkan kelompok haiwan tertentu semenjak ribuan tahun dahulu. Oleh itu, jelas apa yang diucapkan Rasulullah SAW itu benar, tepat dan praktikal sepanjang zaman. Malahan menghilangkan kemudaratan dari segenap arah termasuk ancaman haiwan fasiq adalah dalam ruang lingkup 'amar ma 'rüf, manakala menzalimi dan membunuh haiwan tanpa hak merupakan perkara nahy munkar. Hal ini kerana setiap anjuran Rasulullah SAW bertujuan demi kesejahteraan manusia dan menjadi kewajiban bagi kita untuk mendalaminya signifikan di sebaliknya.

\section{Rujukan}

'Iyāḍ, Al-Qāḍ̄i. Sharh Ṣahīh Muslim li al-Qāḍ̄̄ 'Iyāẹ al-Musamma Ikmal Mu'allim bi Fawā'id Muslim. Mansurah: Dār al-Wafā' li al-Taba'ah wa al-Nashr wa al-Tawzī', 1998.

Abū Dāwūd, Sulaymān Ibn al-Ash'ath al-Sajistānī. Sunan Abū Dāwūd. Riyadh: al-Maktabah al-Ma'ārif li al-Nashr wa alTawzì’, 1988.

Al-Bukhārī, Abū 'Abd Allāh Muḥammad Ibn Ismā'īl. "Al-Jāmi' al-Musnad min Hadīth Rasūl Allāh wa Sunanih wa Ayyāmih," dalam Mawsū'at al-Hadīth al-Sharîf al-Kutub al-Sittah, ed. Șālih Ibn 'Abd al-Azīz Āl al-Syakh. Riyadh: Dār al-Salām li alNashr wa al-Tawzī', 2000.

Al-Bukhārī, Abū 'Abd Allāh Muḥammad Ibn Ismā'īl. Al-Jāmi 'alȘaḥịh al-Musnad min Hadīth Rasūl Allāh wa Sunanih wa 
Ayyāmih. Kaherah: Al-Maktabah al-Salafiyyah wa Maktabatuha, 1980.

Al-Fārisī, 'Alī Ibn Bilbān. Șaḥ̄h Ibn Hibbān bi Tartīb Ibn Bilbān. Beirut: Muassasah al-Risalah, 1993.

Al-Khaț̣abī al-Bustī, Abū Sulaymān Muḥammad. Ma 'âlim alSunan Sharh Sunan Abū Dāwūd. Halab: Matba'ah al-'Ilmiyyah, 1934.

Al-Mubārakfūrī, Muḥammad 'Abd al-Raḥmān Ibn 'Abd al-Raḥīm. Tuhfah al-Aḥwadhī bi Sharh Jāmi' al-Tirmīdhī. T.tp.: Dār alFikr lil Țabā'ah wa al-Nashr wa al-Tawzī', t.t.

Al-Nawāwī, Yaḥyā Ibn Sharf. Al-Minhāj Sharḥ Șaḥịh Muslim. Mesir: Dār Ihyā' al-Turāth al-'Arab̄̄, 1930.

Al-Naysabūrī, Abū al-Husāyn Muslim Ibn al-Hajjāj al-Qushayrī. "Șahīḥ Muslim," dalam Mawsū 'at al-Hadīth al-Sharîf al-Kutub al-Sittah, ed. Șālih Ibn 'Abd al-Azīz Àl al-Shaykh. Riyadh: Dār al-Salām li al-Nashr wa al-Tawzī', 2000.

Al-Qazwaynī, Ibn Mājah. Sunan Ibn Mājah. Riyadh: Maktabah alMa'ārif li al-Nashr wa al-Tawzì’, 1986.

Al-Qurțubī, Abū 'Abd Allāh Muḥammad Aḥmad al-Anșārī. AlJāmi“ li Ahkām al-Qur'ān. Beirut-Lubnan: Dar al-Kutub al'Ilmiyyah, 2006.

Al-Tirmidhī, Abū 'Abd 'Allāh Abū 'Īsā. Sunan al-Tirmìdhì. Riyadh: Maktabah al-Ma'ārif li al-Nashr wa al-Tawzī', 1996.

Al-Wallawī, 'Alī Ibn Ādam Ibn Mūsā al-Ityūbī. Sharh Sunan alNasā'̄̄ al-Musammā Dakhīrah al- 'Uqbā fì Sharh al-Mujtabā. Riyadh: Dār al-Mi'rāj al-Dawliah li al-Nashr, 1996.

Ibn Abī Ḥātim, 'Abd al-Rahmān Muḥammad Idrīs al-Rāzī. Tafsīr al-Qur'ān al- 'Azīm. Makkah-Riyadh: Maktabah Nazār Mușțafā al-Bāz, .

Ibn Hajar al-'Asqalānī, Aḥmad Ibn 'Alī. Fath al-Bārī bi Sharh Șaḥịh al-Bukhārī. Riyadh: Fahrasah Maktabah Malik Fahd alWataniah Ithnaā' Nashr, 2001.

Ibn Hajar al-'Asqalani, Fath al-Bari bi Sharh Șaḥ̄h al-Bukhārī, terj. Amiruddin et al. Jakarta: Pustaka Azzam Penerbit Buku Islam Rahmatan, 2006.

Ibn Kathīr al-Dimashqī, 'Ismā'īl. Tafsìr al-Qur'ān al-'Azìm. Kaherah: al-Farūq al-Ḥadīthiyyah li al-Tabā'ah wa al-Nashr, 2000. 
Ibn Yūsuf al-Sanusī al-Ḥasan̄̄, Muḥammad Ibn Muḥammad. Mukammil Ikmāl al-Ikmāl Sharh Ṣah̄̄h Muslim. Beirut-Lubnan: Dar al-Kutub al-'Ilmiyyah, t.t.

Kamus Dewan Online, laman sesawang Pusat Rujukan Persuratan Melayu (PRPM), dicapai pada 20 September 2013, http://prpm.dbp.gov.my/Search.aspx?k=haiwan+perosak

Manzur, Ibn. Lisān al- 'Arab. Kaherah: Dar al-Ma'ārif, t.t.

Monika@Munirah Abd Razak, Nik Mohd Zaim Ab Rahim, "Hadith-Hadith Mengenai Anjing: Tumpuan Kepada Isu Pemeliharaan dan Pengharamannya Daripada Perspektif Hadith Ahkam," dalam Seminar Antarabangsa Sunnah Nabawiyyah: Realiti dan Cabaran Semasa (MUSNAD I), ed. Fauzi Deraman, Ishak Suliaman dan Faisal Ahmad Shah, Jabatan al-Quran \& alHadith, Akademi Pengajian Islam, Universiti Malaya, 2011), 526-532.

Muḥammad Shams al-Ḥaq al-'Azịim Ābādī, Abū al-Ṭayyīb. 'Awn al-Ma 'būd Sharh Sunan Abū Dāwūd. Madinah al-Munawwarah: al-Maktabah al-Salafiah, 1968. 
Lampiran 1:

Perkaitan Haiwan Fasiq Dengan Haiwan Perosak Masa Kini

\begin{tabular}{|c|c|c|}
\hline $\begin{array}{c}\text { Haiwan } \\
\text { Fasiq }\end{array}$ & Tabiat/Sifat & $\begin{array}{c}\text { Spesies Haiwan Lain } \\
\text { Sama Tabiat/Sifat } \\
\text { (Haiwan Perosak) }\end{array}$ \\
\hline Tikus & $\begin{array}{l}\text { Pengotor } \\
\text { Pembawa } \\
\text { penyakit } \\
\text { Memotong- } \\
\text { motong dan } \\
\text { merosak harta } \\
\text { benda } \\
\text { Merosak hasil } \\
\text { tanaman } \\
\end{array}$ & $\begin{array}{c}\text { Lipas } \\
\text { Belalang Juta } \\
\text { Burung Quelea paruh merah } \\
\text { Tupai } \\
\text { Gajah } \\
\text { Siput Babi } \\
\text { Khinzir } \\
\text { Anai-anai }\end{array}$ \\
\hline $\begin{array}{c}\text { Kala } \\
\text { Jengking }\end{array}$ & $\begin{array}{l}\text { Berbisa } \\
\text { Memudaratkan } \\
\text { manusia } \\
\text { Berupaya } \\
\text { membunuh }\end{array}$ & $\begin{array}{c}\text { Lipan } \\
\text { Tebuan } \\
\text { Penyengat } \\
\text { Labah-labah berbisa }\end{array}$ \\
\hline $\begin{array}{l}\text { Burung } \\
\text { Gagak }\end{array}$ & $\begin{array}{l}\text { Pengotor } \\
\text { Pemakan bangkai } \\
\text { Pembawa } \\
\text { penyakit } \\
\text { Mengganggu } \\
\text { manusia dengan } \\
\text { bunyi yang bising } \\
\text { Mencuri dan } \\
\text { merampas } \\
\text { makanan manusia }\end{array}$ & $\begin{array}{l}\text { Burung hering } \\
\text { Monyet } \\
\text { Kera }\end{array}$ \\
\hline $\begin{array}{l}\text { Burung } \\
\text { Helang }\end{array}$ & $\begin{array}{l}\text { Ganas } \\
\text { Menyambar } \\
\text { dengan kuku } \\
\text { tajam } \\
\text { Mengancam } \\
\text { haiwan ternakan } \\
\text { manusia }\end{array}$ & $\begin{array}{l}\text { Musang } \\
\text { Biawak } \\
\text { Babun }\end{array}$ \\
\hline
\end{tabular}




\begin{tabular}{|c|c|c|}
\hline $\begin{array}{c}\text { Haiwan } \\
\text { Fasiq }\end{array}$ & Tabiat/Sifat & $\begin{array}{c}\text { Spesies Haiwan Lain } \\
\text { Sama Tabiat/Sifat } \\
\text { (Haiwan Perosak) }\end{array}$ \\
\hline Anjing & $\begin{array}{l}\text { Bengis } \\
\text { Pembawa } \\
\text { Penyakit (contoh; } \\
\text { Rabies) } \\
\text { Mengancam } \\
\text { manusia dan } \\
\text { haiwan ternakan } \\
\text { dengan gigi dan } \\
\text { taring yang kuat } \\
\text { Boleh } \\
\text { menyebabkan } \\
\text { kematian serta } \\
\text { merta }\end{array}$ & $\begin{array}{c}\text { Anjing liar } \\
\text { Harimau } \\
\text { Harimau kumbang } \\
\text { Harimau bintang } \\
\text { Serigala } \\
\text { Beruang } \\
\text { Singa } \\
\text { Buaya } \\
\text { Aligator } \\
\text { Ikan jerung } \\
\text { Piranha }\end{array}$ \\
\hline Ular & $\begin{array}{l}\text { Berbisa } \\
\text { Memusuhi } \\
\text { manusia } \\
\text { Boleh } \\
\text { menyebabkan } \\
\text { kematian serta } \\
\text { merta }\end{array}$ & $\begin{array}{c}\text { Semua jenis ular berbisa } \\
\text { seperti ular tedung, ular } \\
\text { mamba hitam dan ular kapak } \\
\text { Ular yang tidak mempunyai } \\
\text { bisa tapi menggigit dengan } \\
\text { gigi tajam seperti ular sawa } \\
\text { dan anaconda hijau } \\
\text { (spesies ular terbesar di } \\
\text { dunia) }\end{array}$ \\
\hline Cicak & $\begin{array}{l}\text { Haiwan kecil yang } \\
\text { gemar } \\
\text { mengganggu } \\
\text { manusia } \\
\text { Suka membuang } \\
\text { najis merata-rata } \\
\text { Pembawa virus } \\
\text { dan bakteria } \\
\text { berbahaya } \\
\end{array}$ & $\begin{array}{c}\text { Virus } \\
\text { Bakteria } \\
\text { Pijat } \\
\text { Kutu } \\
\text { Nyamuk } \\
\text { Lalat }\end{array}$ \\
\hline
\end{tabular}


Lampiran 2:

Pendekatan Dalam Interaksi Manusia Terhadap Haiwan Fasiq (Haiwan Perosak)

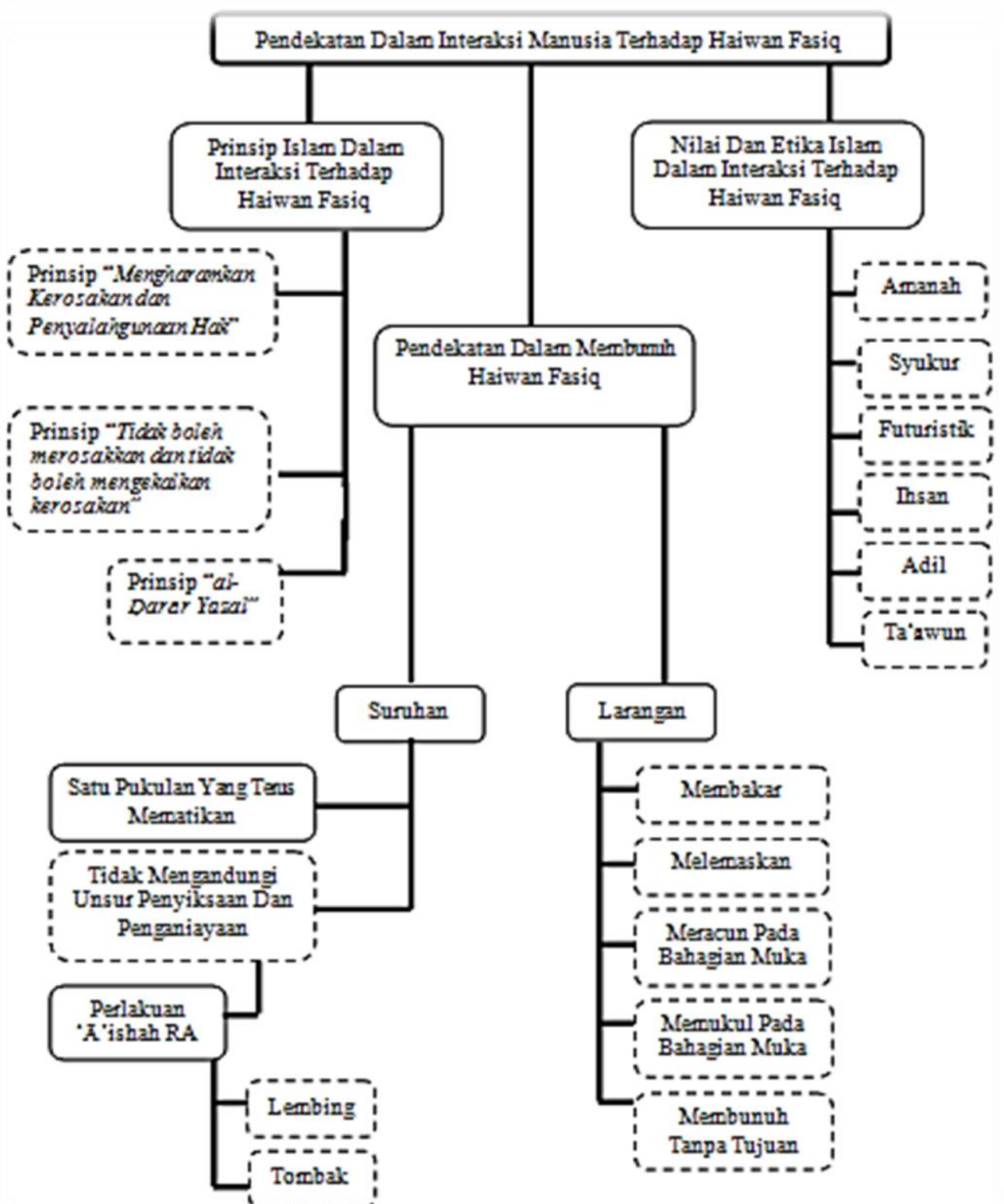


Farhan, Adam dan Za'im, Ancaman Ular 